\title{
Corporate Yield Spread and Real Activity in Emerging Asia: Evidence of a Financial Accelerator for Korea
}

\author{
Stephanos Papadamou \\ University of Thessaly \\ Costas Siriopoulos \\ University of Patras
}

\begin{abstract}
This paper investigates the relationship between corporate bond market and real economic activity. A linear model is estimated by using the Generalized Method of Moments (GMM) indicating that the yield spread of corporate bonds (AA-) relative to government bonds - a proxy of liquidity and default risk, known as external finance premium (EFP) - predicts changes in unemployment rate up to six months in the future. An impulse response analysis based on a multivariate VAR shows that a temporary increase in EFP, leads to a persistent increase in unemployment rate, notably after two to eight months. The response of unemployment rate to monetary policy shock is much lower when channel acting through the EFP is blocked off. This evidence is consistent with an operative balance sheet channel of the monetary transmission mechanism, an important result for policy makers and investors. Consequently an efficient and liquid corporate bond market, achieved through financial integration, is of essential meaning for economic growth in Korea.
\end{abstract}

•JEL Classification : E44, E52

- Key Words : economic fluctuations, monetary policy, transmission mechanism, credit channel, VAR models

*Corresponding address: Stephanos Papadamou: Lecturer of Monetary and Banking Economics, Department of Economics, University of Thessaly, Korai 43, Post Code 38333, Volos, Greece, Tel: 0030-24210-74963, e-mail: stpapada@uth.gr, Costas Siriopoulos: Professor of Quantitative Methods in Finance, Dept. of Business Administration, University of Patras, Hellas, University Campus, 26500 Rion, Patras, Hellas, Greece, Tel: 0030-2610-996394, e-mail: siriopoulos@eap.gr. @2009-Center for International Economics, Sejong Institution, Sejong University, All Rights Reserved. 


\section{Introduction}

There are a number of reasons why developments in corporate bond market may play a crucial role in the economy. First of all, this market is an important conduit between savings and investments, enabling borrowers to issue publicly traded debt instruments in order to finance their investment projects and or other corporate spending.

In addition there is a long tradition in economic theory that investigates the interaction between financial variables behaviour and business cycle fluctuations. A broad literature originating in the late 1980s documents the empirical regularity that the slope of the yield curve is a reliable predictor of real economic activity. According to Estrella and Hardouvelis (1991) the difference between the 10-year government bond rate and the 90-day T-bill rate, known as term spread, has borne a consistent relationship with subsequent real activity in the United States, with a lead time of about four to six quarters. However, recent literature (Mody and Taylor, 2003) in United States has replaced term spread by quality yield spread due to the weakness of the former in forecasting economic activity over the last decade.

Furthermore, several recent empirical studies in the literature of information asymmetries in credit markets have emphasized on the importance of the balance sheet channel for the transmission of the monetary policy (see among others De Bondt, 2000; Ashcraft and Campello, 2007). On the theoretical side, the balance sheet channel can be defined as the variation in price and availability of external finance induced by monetary policy. Financial accelerator plays a key role in this monetary transmission channel. Bernanke, Gertler and Gilchrist (1996) developed financial accelerator theory, which suggests that the premium for external finance, which can be poxied by the corporate spread to a risk free security, depends inversely on the net worth of the firm. Since net worth exhibits procyclical pattern, an increase in the external finance premium, is associated with economic slowdown.

The corporate yield spread, is a measure of the risk premium corporations pay investors to compensate them for a number of risk associated with corporate debt, such as liquidity and default risk. Default risk, in particular, is clearly affected by current and expected economic conditions. The ability of the corporations to be consistent in their obligations depends mainly on their net worth and earning prospects, which are affected by current stage of the business cycle and investors' expectations about the future strength of the economy. The use of such a spread 
can be justified by the financial accelerator theory, as well as, by the fact that financial markets are relatively quick and efficient in pricing new information, and that financial yields are available at high frequencies.

Previous literature is focused on the term spread as useful predictor of economic activity in global economies. However, recent findings concerning U.S. underline the significant role of the corporate yield spread instead of the term spread. Up to date, only few studies have tested this finding for other economies. This is due to the lack of an equally developed corporate bond market in the whole world. During last decade South Korea figures among the three biggest corporate bond issuers with an average of 193,52 billions $\$$ or $5 \%$ of world corporate bond issuers.

The theoretical underpinning of the quality spread as predictor of real economic activity primarily relates to the theory of financial accelerator (see for example Bernanke \& Gertler, 1995; Bernanke Gertler and Gilchrist, 1996). According to this theory, the balance sheet channel arises because rising interest rates, following tight monetary policy, directly increase the interest expenses of the non-financial firms who rely heavily on the debt market to finance investment decisions, reducing their net cash flows and weakening their balance sheet positions. Further rising of interest rates are also associated with falling asset prices, which indirectly shrink the value of the firms' collateral. These effects lead to a reduction of the firms' net worth, thereby raising the premium for external finance (a wedge between the cost of funds raised externally and the opportunity cost of internal funds). This theory emphasizes the role of credit market imperfections and of borrowers' balance sheets in reducing incentive problems and thus agency costs, in credit markets.

The first papers in the literature that relates output with credit risk are focused on the paper-bill spread (Bernanke and Blinder 1992; Friedman and Kuttner 1992; Kashyap, Stein and Wilcox, 1993). This spread, usually rises before recessions mainly because the reduction of bank credits leads firms to issue more commercial papers. Such a reduction of bank credit may be the consequence of a tighter monetary policy, and it is usually followed by a recession. However, this paper-bill spread as leading indicator faces two problems! Firstly, this spread refers to shortterm debt instruments and reflects mainly liquidity risk and not credit risks or in other words investors' expectations about business cycles in the future. Secondly, commercial paper and treasury bills are almost a perfect substitute due to the fact that only corporations with low default risk can issue commercial paper (Friedman and Kutner 1998). Moreover, Duca (1999) documents that increase in default risk 
are correlated with economic downturns, and, consequently, default premiums tend to rise during recessions.

Based on this argumentation against paper-bill spread the research in United States focuses on the corporate-government bond yield spread. Many studies show that this quality spread is performed very satisfactorily as a leading indicator of future economic activity (among others Estrella and Mishkin, 1998, Chan-Lau and Ivaschenko, 2001, Mody and Taylor, 2004).

Gertler and Lown (1999), by studying US data for the period 1980-1999, based on correlation and impulse response analysis, find that the yield spread between high yield to AAA-rated bonds can explain output gap more satisfactorily than other indicators, including the term spread, the paper bill and the Federal Funds rate. Additionally, Mody and Taylor (2003) find that the high yield spread between "junk bond" and government bond yields works through both the demand and the supply side of the economy. Ashcraft and Campello (2007) by investigating small subsidiary banks that are affiliated with the same holding company, find a demanddriven transmission mechanism that works through firm balance sheets and is independent from the bank lending channel.

In European individual countries, empirical evidence for the financial accelerator theory, is provided among others by Dale and Haldane (1995), Chrystal and Mizen (2002), for UK, Buttiglione and Ferri (1994) for Italy, Escriva and Haldane (1994) for Spain. According to Cecchetti (1999) and Fountas and Papagapitos (2001), the importance of the credit channel will differ based on heterogeneity of financial structure among European countries. According to Gallegati (2005), the inclusion of internal funds in the augmented IS/LM fixed price model suggests a different interpretation of the 'balance sheet channel' as an enhancement mechanism amplifying monetary policy effects through the quantity rather than the cost of borrowing. The empirical analysis of the monetary transmission mechanism for Italy in the last decade accords with this interpretation of the balance sheet channel. De Bondt (2004) is the first that provides evidence for an operative balance sheet channel in European Union by using aggregate data.

Among studies including more than one country and making international comparisons Barran, et al. (1997) are investigated the role of various financial spreads in forecasting economic activity in five OECD countries (United States of America, United Kingdom, Japan, France, Germany).

In Japan, Nagahata and Sekine (2005) find that the deterioration in balance-sheet conditions, especially in bank balance-sheet conditions, hampered investment by 
smaller non-bond-issuing firms more severely than that by larger bond-issuing firms. Evidence of an operative lending channel of monetary transmission in Japan, is provided by Hosono, K. (2006). He states that the effect of expansionary monetary policy is attenuated if banks' capital is scarce, and that the effect of monetary policy on the allocation of funds depends on banks' balance sheets.

Studies concerning Korean economy are focused on the period before the financial crisis of 1997-1998 and mainly on the bank lending channel rather than the balance sheet channel of monetary policy. In addition, the years following the financial crisis of 1997-1998, the government of South Korea, has sought to generate economic recovery by expanding domestic credit. It is therefore, interesting to investigate the role of the domestic bond market in economic activity during the whole period from 1995 to 2006.

Ding, Domac and Ferri (1998), Domac and Ferri (1998), and Kim (1999), by investgating the transmission mechanism of monetary policy in Korea, find that the banking sector plays an important role, a result consistent with the bank lending channel theory. However, these studies are focused on the bank lending channel rather than the balance sheet channel, over a sample periods that ends in 19971998. Hahm and Mishkin (2000) analyse the Korean financial crisis in 1997 by using an asymmetric information framework and investigating macro and microeconomic data. Based on these studies particular attention should be given to the role of the corporate bond markets in the transmission mechanism of the monetary policy to real economic activity during the whole period from 1995 to 2006.

The main objective of this paper is to investigate whether the corporate bond spread can be served as one effective leading indicator of economic activity in Korea, and whether the balance sheet channel, working through the corporate bond market, is a key to monetary transmission mechanism in Korea. Understanding the transmission mechanism of monetary policy-especially any time lag involved between a policy change and its impact on economic activity- is the key to the successful conduct of policy. Economic activity is proxied by the unemployment rate because of its broad coverage of the economy and its stability (NBER, 2001). In addition unemployment rate reflects in a more relevant way the relation between net worth of corporations and economic output in the context of the balance sheet channel theory. The combination of information provided by both the term spread and external finance premium variable is crucial in forecasting unemployment rate changes. In addition this information would be useful to domestic and foreign 
investors as well as policymakers in Korea.

The rest of the paper is organized as follows. Section II provides information about the data and the main methodology of our research. In section III , estimation results are presented and compared. Finally, section IV concludes with some general comments.

\section{Methodology and Data}

The important role of the corporate bond spread (or external finance premium, EFP) can be resulted from the fact that Korea has a developed corporate bond market (see table 1 and fig. 1) and can be served as a major source of external funds. Moreover, under realistic conditions of information asymmetry, corporate bonds contain special information. Therefore, it is worthwhile to define the role of the corporate bond spread in the transmission channels of monetary policy to real economy.

The goal of the paper is to investigate the possible significant role of the corporate bond spread on economic activity. In order to test the robustness of our results two different empirical methods are used: a) Generalised Methods of Moments and b) impulse responses based on multivariate unrestricted vector autoregressive (VAR) models.

Table 1. Domestic Non-financial Debt Securities by Residence of Issuer. Amounts Outstanding (in Billions of US Dollars) for the Period Sep. 1995 - Sep. 2006

\begin{tabular}{ccrrr}
\hline Rank & Corporate issuers & Average & $\%$ of Total & Rate of Change \\
\hline 1 & United States & 2282,41 & $57 \%$ & $64 \%$ \\
2 & Japan & 616,16 & $15 \%$ & $34 \%$ \\
3 & South Korea & 193,52 & $5 \%$ & $160 \%$ \\
4 & France & 157,68 & $4 \%$ & $218 \%$ \\
5 & Italy & 93,24 & $2 \%$ & $1701 \%$ \\
6 & Spain & 83,41 & $2 \%$ & $636 \%$ \\
7 & Canada & 81,50 & $2 \%$ & $130 \%$ \\
8 & Australia & 55,94 & $1 \%$ & $780 \%$ \\
9 & Taiwan & 55,52 & $1 \%$ & $120 \%$ \\
10 & Germany & 53,78 & $1 \%$ & $1254 \%$ \\
\hline \multicolumn{5}{c}{ Total in all over } \\
\hline
\end{tabular}

Source: BIS Quarterly Review, March 2007 
Figure 1. Evolution of Non-financial Debt Securities as \% of Total Amount Outstanding in all over the World

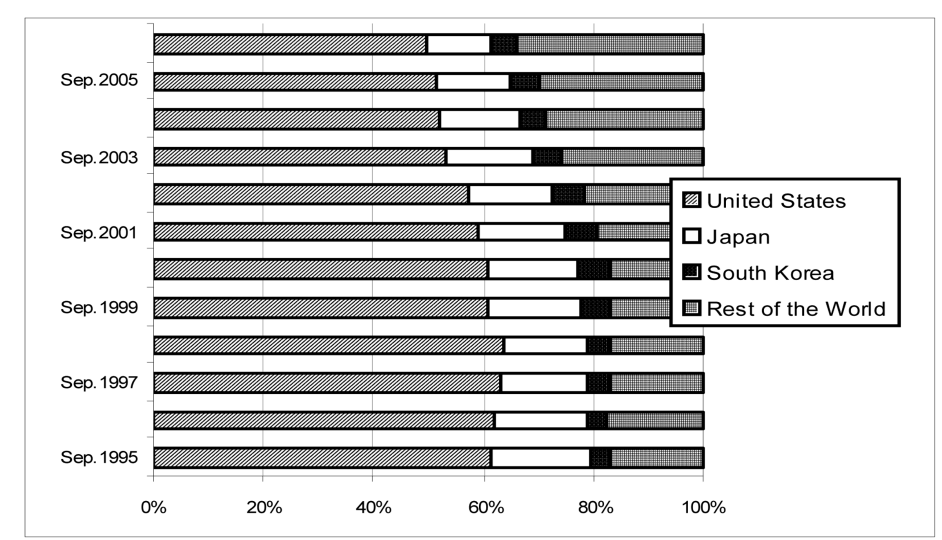

Source: BIS Quarterly Review, March 2007

\section{A. Estimating the Relationship between Economic Activity and EFP by Using GMM}

A linear relationship between the change on unemployment rate and external finance premium is investigated by estimating the following equation:

$$
Y_{t}(k)=X_{t}^{\prime} \beta+u_{t}
$$

where the dependent variable in our analysis is the future change of unemployment rate, over the period $t$ to $t+k$, measured by the following equation:

$$
Y_{t}(k)=\Delta U N R_{t}^{k}=\left(U N R_{t+k}-U N R_{t}\right)
$$

$k$ denotes the forecasting horizon in months and $X_{t}$ is a $(2 \times 1)$ vector consisting of 1 and of the external finance premium defined as the difference between corporate and treasury bond yield of the same maturity.

$$
E F P_{t}=c b y_{t}^{3 y}-t b y_{t}^{3 y}
$$

Mainly because the external finance premium is a forward looking variable the model is estimated by using the Generalized Method of Moments (GMM) introduced by Hansen in 1982. A major problem with forward-looking variables is 
that they may be correlated with the error term, leading to biased estimates of the coefficients of interest. In addition, the error term may experience non-normality, autocorrelation and heteroskedasticity, causing problems with respect to statistical inference. It is now common to use Generalized Method of Moments (GMM) which allows conditioning the estimation on the information set available at time $t$, $\Omega_{t}$, and relaxing the assumptions about the distribution of residuals. ${ }^{1}$ However, because the regressors can be endogenous with respect to the dependent variable, as suggested by previous work relating economic activity and external finance premium, the condition can not be imposed. Instead a vector of instrumental variables, orthogonal to the error term is used under the following moment conditions:

$$
E_{t}\left[\left(Y_{t}-X_{t}^{\prime} \beta\right) \otimes Z_{t}\right]=0_{4 x 1}
$$

where $Z_{t}^{\prime}=\left(Y_{t-1}, Y_{t-2}, X_{t-1}, X_{t-2}\right) .^{2}$ Using instruments we ensure that the GMM estimates of $\mathrm{b}$ are still consistent. Moreover imposing (two) overidentifying restrictions improves the efficiency of estimators. The overlapping observations induce a moving average process in the error term. Therefore, the Newey-West (1987) technique is used to correct for autocorrelation and heteroskedasticity. The goodness of fit of the model is tested by using the over identifying restrictions test (Hansen, 1982).

\section{B. The Role of EFP in a Multivariate VAR - Impulse Response Analysis}

The EFP is treated as endogenous variable in a VAR framework (see, Bernanke and Gertler, 1995). By assuming that the economy is described by a linear, stochastic dynamic system, a multivariate VAR model is estimated. In such a model we can assess the speed and degree of adjustment of the change in unemployment rate due to a shock on a series of financial variables. The VAR model captures the dynamic feedback effects in a relatively unconstrained fashion and is therefore a good approximation to the true data generating process. We express the VAR model as:

$$
Z(t)=C+\sum_{s=1}^{m} A(s) Z(t-m)+v(t)
$$

where $\mathrm{Z}(\mathrm{t})$ is a column vector of the variables under consideration [(a) the

${ }^{1}$ For more details about GMM estimation method see Davidson and McKinnon (1993), Verbeek (2004).

${ }^{2}$ For instrument selection see Gallant and Tauchen (1996). 
unemployment rate $U N R_{\mathrm{t}},(\mathrm{b})$ the rate of change of the consumer price index $\Delta(\log$ $C P I)_{\mathrm{t}},(\mathrm{c})$ the short-term money market rate $M M R_{t}$ and (d) the corporate bond spread $\left.E F P_{\mathrm{t}}\right]$. C is the deterministic component comprised of a constant. In addition to the constant term the VAR also contains the Won/\$ exchange rate as an exogenous variable to control for the currency crisis in late $1997 .{ }^{3} \mathrm{The} A(\mathrm{~s})$ is a matrix of coefficients, $\mathrm{m}$ is the lag length and $v(t)$ is a vector of random error terms. ${ }^{4}$ By construction, $v(t)$ is uncorrelated with past $\mathrm{Z}(\mathrm{t}) \mathrm{s}$.

The VAR specification allows the researchers to make a policy simulation and integrate Monte Carlo methods to obtain confidence bands around the point estimates (Hamilton, 1994). The likely response of one variable at time $t, t+1, t+2$ etc to a one time unitary shock in another variable at time $t$ can be captured by impulse response functions. As such they represent the behavior of the series in response to pure shocks while keeping the effect of other variables constant. Since, impulse responses are highly non-linear functions of the estimated parameters, confidence bands are constructed around the mean response. Responses are considered statistically significant at the $95 \%$ confidence level when the upper and lower bands carry the same sign.

Sims, Stock and Watson (1990), argue that a VAR model in levels in the presence of cointegration is over-parameterized and, therefore, leads to inefficient but consistent estimates of the parameters of interest. The loss of efficiency has to be weighted against the risk of inconsistency of estimates which occurs when the wrong cointegrating restrictions are imposed. Imposing the wrong cointegrating parameters will make the system converge to the long-run equilibria, but will also bias short-run dynamics, as the system is pulled in the wrong direction. For this reason the recent research has taken a defined line and VARs in levels rather than cointegrated VARs are used when the issue of economic interest is related to the short-run rather than the long-run (Favero, 2001). Given that some of the variables in the model are likely to be non-stationary (the unemployment rate, the logarithm of consumer price index and the money market rate are stationary in first

\footnotetext{
${ }^{3}$ Contemporaneous and lagged (up to 6 lags) Won $/ \$$ rate, seem to be able to capture the large residuals associated with the crisis (i.e. to correct any normality problems) and it is more satisfactory, from an economic point of view, than including a crisis dummy.

${ }^{4}$ Diagnostic tests (Jarque-Bera test for normality, F-statistic versions of Breusch-Godfrey test for autocorrelation and the $\mathrm{ARCH}$ test) on residuals from estimation of equation 5 do not indicate any problem concerning autocorrelation, heteroskedasticity and normality issues.

${ }^{5}$ The Augmented Dickey Fuller and Phillips-Perron tests have been applied. Moreover, the Elliot, Rothenberg and Stock (1996) test and the modified Z tests of Perron and Ng (1996) because they have superior power and size properties compared to the first two.
} 
differences $)^{5}$ and the fact that the VAR model involves variables admitting stationary linear combinations, ${ }^{6}$ we estimate VAR in levels. A VAR in first differences provides no information on the relationship between levels of the variables in the VAR, and it is this aspect on which economic theory is most informative.

\section{Data Description}

In our study monthly data are used for the period 1995:05 - 2006:12. The sample size is selected based on the availability of monthly data from the Bank of Korea. ${ }^{7}$ With the reorganization of the trust account system in April 1996, Korea's leading monetary indicator, M2, began to show unstable movement. Even if the shift of operating target from reserves to the overnight call rate was not undertaken at a specific point in time, from the mid-1990s Korea has been starting to focus on a monetary policy regime that targeted interest rates.

The short term interest rate is proxied by the overnight money market rate (MMR) and the external finance premium (EFP) or corporate yield spread, is defined as the difference between the corporate bond yield (rated AA-) with three years maturity (CB3Y) and the treasury bond yield (TB3Y) with the same maturity. The selection of AA- rated bonds is based on the fact that this category of bonds has higher risk than the three AAA rated bonds. As a result the external finance premium can reflect liquidity and default risk. The level of economic activity has been proxied by the standardized unemployment rate $\left(\mathrm{UR}^{8}\right)$. We choose this last variable because of its broad coverage of the economy and its stability. Moreover, the National Bureau of Economic Research in U.S. (NBER) business cycle dating committee states in a recent report (2001) that "employment is probably the single most reliable indicator of economic activity" at a monthly frequency.

\section{Analysis of Empirical Results}

Equation four is estimated using the corporate bond spread over treasuries for three years maturity as an explanatory variable. Its predictive power is tested for 2 , 3, 6, 9 and 12 months horizon. The results of the single equation GMM estimates

\footnotetext{
${ }^{6}$ Cointegration tests based on Johansen procedure do not presented for economy of space.

${ }^{7}$ Data for treasury bonds with maturity 3 years have been available only after May of 1995

${ }^{8}$ Source OECD.
} 
Table 2. Results of GMM Estimations

\begin{tabular}{ccccccccccc}
\hline \multicolumn{1}{c}{ Part A } & \multicolumn{5}{c}{ Part B } \\
\hline \multicolumn{3}{c}{ Explanatory Variable: EFP } & \multicolumn{3}{c}{ Explanatory Variables: EFP, Term Spread } \\
\hline & $\mathrm{a}$ & $\mathrm{b}$ & $\begin{array}{c}\text { J-statistic } \\
\text { (p-value) }\end{array}$ & Adj. $\mathrm{R}^{2}$ & $\mathrm{a}$ & $\mathrm{b}_{\text {EFP }}$ & $\mathrm{b}_{\text {Term Spread }} \begin{array}{c}\text { J-statistic } \\
\text { (p-value) }\end{array}$ & Adj. $\mathrm{R}^{2}$ \\
$\mathrm{k}=2$ & -0.12 & 0.18 & $(0.30)$ & 0.27 & 0.01 & 0.13 & -0.07 & $(0.15)$ & 0.54 \\
& $(0.21)$ & $(0.00)^{* *}$ & & & $(0.83)$ & $(0.00)^{* *}$ & $(0.00)^{* *}$ & & \\
$\mathrm{k}=3$ & -0.25 & 0.28 & $(0.17)$ & 0.27 & -0.03 & 0.30 & -0.15 & $(0.20)$ & 0.50 \\
& $(0.09)$ & $(0.00)^{* *}$ & & & $(0.06)$ & $(0.00)^{* *}$ & $(0.00)^{* *}$ & & \\
$\mathrm{k}=6$ & -0.63 & 0.69 & $(0.18)$ & 0.13 & -0.13 & 0.25 & -0.19 & $(0.63)$ & 0.54 \\
& $(0.05)^{* *}$ & $(0.00)^{* *}$ & & & $(0.63)$ & $(0.05)^{* *}$ & $(0.00)^{* *}$ & & \\
$\mathrm{k}=9$ & -0.31 & 0.39 & $(0.89)$ & 0.10 & -0.22 & 0.29 & -0.23 & $(0.95)$ & 0.35 \\
& $(0.41)$ & $(0.16)$ & & & $(0.34)$ & $(0.01)^{* *}$ & $(0.00)^{* *}$ & & \\
$\mathrm{k}=12$ & -0.74 & 0.45 & $(0.93)$ & 0.01 & 0.07 & 0.24 & -0.17 & $(0.98)$ & 0.11 \\
& $(0.28)$ & $(0.27)$ & & & $(0.73)$ & $(0.22)$ & $(0.00)^{* *}$ & & \\
\hline
\end{tabular}

Note: Asterisk $\left({ }^{*}\right)$ and $\left(^{* *}\right)$ mean statistically significant values at $90 \%$ and $95 \%$ level of significance. Jstatistic p-values indicate evidence for the validity of instruments. Term Spread is defined as the difference between long and short term rates.

are presented on part A of table 2. These findings indicate that the coefficient of the corporate spread variable is significant at 5 percent level at 2 to 6 months horizon. As expected from the financial accelerator theory, an increase in the corporate spread signals an increase on unemployment rate change that is equivalent to a decline in economic activity in the future. We should also mention at this point that by using as another explanatory variable the difference between the yields of non-financial corporations characterized as AA- to the financial corporations characterized as AAA, the results are similar.

Another interesting statistic presented in table 2 is the J-statistic that can be used to carry out hypothesis tests from GMM estimation (Newey and West, 1987). A simple application of the J-statistic is to test the validity of overidentifying restrictions when you have more instruments than parameters to estimate (or in other words to test the validity of instruments). Under the null hypothesis that the overidentifying restrictions are satisfied, the J-statistic times the number of regression observations is asymptotically characterized as $X^{2}$ with degrees of freedom equal to the number of overidentifying restrictions. In table 2 we present the p-value of the test statistic that indicates evidence for the null hypothesis of the validity of instruments in our models.

In order to assess the statistical significance of the results, the popular variable of the term structure of interest rates (Term Spread) defined as the difference between 
Figure 2. Responses to Cholesky One S.D. Innovations \pm 2 S.E.

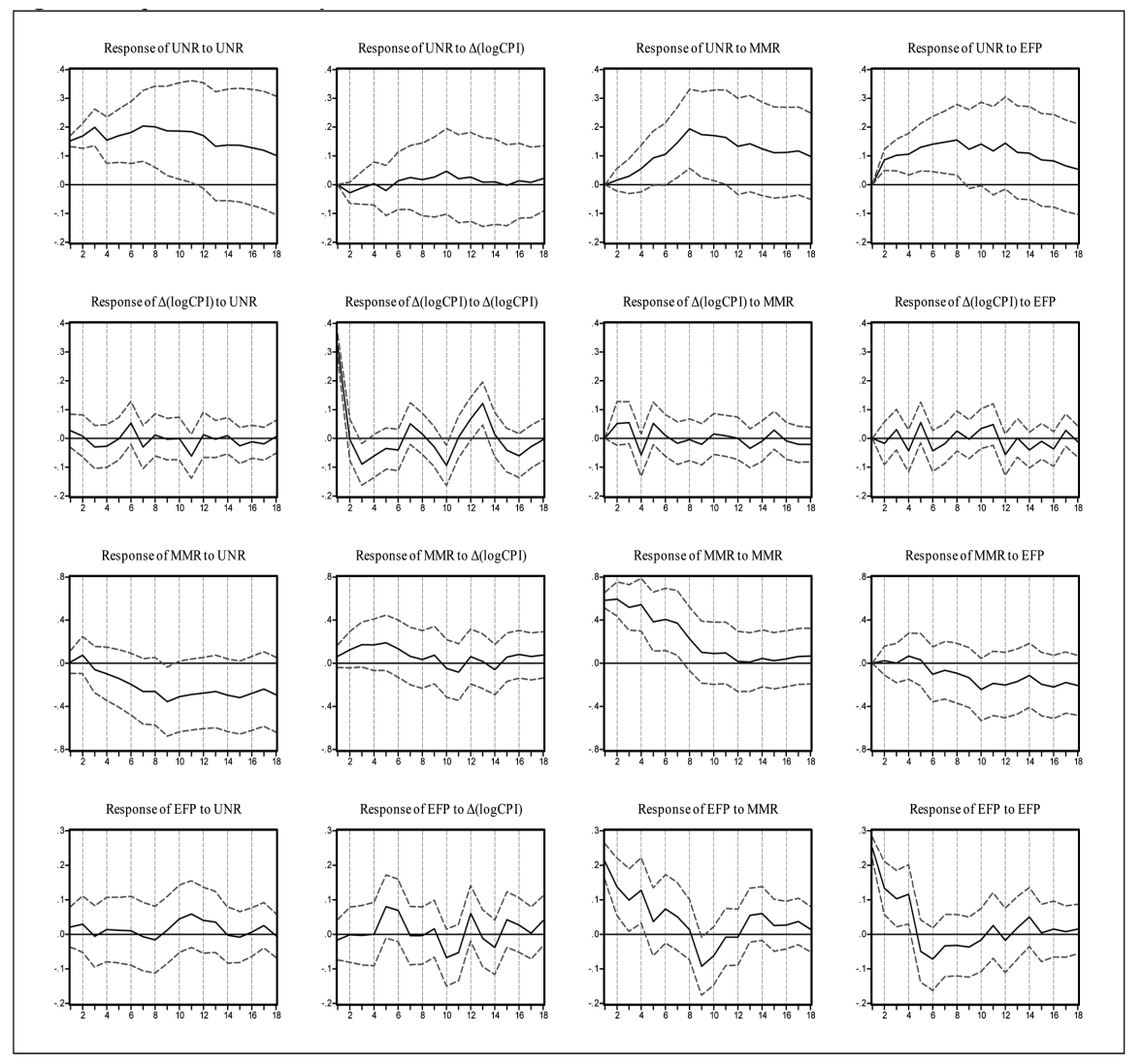

the long -term (National housing bond yields with 5 years maturity, NH5Y) and the short-term (money market rate, MMR) rates, is added into the vector $X$ of equation (1). The results presented on part B of table 2 , indicate that statistical significance of the external finance premium coefficient $\left(b_{\mathrm{EFP}}\right)$ does not decline after the inclusion of the term structure variable. Another interesting point is the increase of the adjusted $\mathrm{R}$-squared to $50 \%$. Finally the term structure variable is significant and after 6 months horizon, a result consistent with many papers in such an area [among others, Hardouvelis and Estrella, $(1991,1998)$ Hamilton and Kim (2002), Paya and Matthews (2004), Papadamou (2007)].

In order to identify any possible relation of EFP variable with other important macroeconomic variables in a multivariate VAR model, we estimate a model that includes the unemployment rate, the logarithm of consumer price index in first differences, the money market rate (an indicator of monetary policy) and the external finance premium. The estimation is done using monthly, seasonally 
adjusted data from May 1995 to December 2006 with 12 lags. The number of lag length is identified by using the various information criteria (Akaike, Scharz etc) and by taking into account that if we take a too short lag length we cannot capture the underlying dynamics of the system. On the other hand, we quickly run into a degrees of freedom problem if we include too many lags. The VAR is identified by using a 'recursive' Choleski decomposition with the ordering of variables as listed above. The results are fairly robust to alternative ordering.

In figure 2 we present the impulse response functions from the VAR model estimated. Theses functions, basically trace out the implied dynamic paths of the endogenous variables in the system following a one-time shock to one of the innovations. The solid line represents the mean response and the dashed lines are confidence bands around the mean response. A total of 500 draws were employed in the Monte Carlo simulations to obtain the standard errors. The responses are said to be statistically significant when the dashed responses carry the same sign. An unexpected tightening of monetary policy - corresponding approximately to a 0.60 $\%$, rise in the short-term rate - gives a rise to a positive response of unemployment rate variable which reaches it's peak after eight months. The response of the EFP to the tightening of the monetary policy is positive and quite persistent.

Concerning an external finance premium shock - corresponding approximately to a $0.25 \%$ rise in the corporate bond spread - it can be easily seen that it has a positive and statistically significant effect on the unemployment rate. This effect is quite persistent and statistically significant for almost nine months after the initial shock. Finally, external finance premium reacts positively to the monetary policy shock indicating the important role that corporate bond market may play in monetary transmission mechanism.

While impulse response functions trace the effects of a shock to one endogenous variable on to the other variables in the VAR, variance decomposition separates the variation in an endogenous variable into the component shocks to the VAR. Thus, the variance decomposition provides information about the relative importance of each random innovation in affecting the variables in the VAR. To get an idea of the share of the fluctuations in a given variable that are caused by different shocks, table 3 presents variance decompositions for each variable at forecast horizons of three to nine months. The columns give the percentage of the variance due to each shock, with each row adding up to $100 \%$. The results indicate that after six months money market rate and external finance premium account for around $32 \%$ of the fluctuation in unemployment rate, with own shocks accounting for the rest. Interest 
Table 3. Variance Decomposition for the VAR Model

\begin{tabular}{ccccc}
\hline Forecast Horizon & UNR & $\Delta(\log C P I)$ & MMR & EFP \\
\hline Variance Decomposition of UNR: & & & & \\
3 months & 82.10 & 0.83 & 1.04 & 16.03 \\
6 months & 65.94 & 0.58 & 8.92 & 24.56 \\
9 months & 54.72 & 0.58 & 21.06 & 23.64 \\
Variance Decomposition of $\Delta(\log$ CPI): & & & & \\
3 months & 1.40 & 92.94 & 4.64 & 1.02 \\
6 months & 3.60 & 82.53 & 8.20 & 5.67 \\
9 months & 4.20 & 81.40 & 8.35 & 6.05 \\
Variance Decomposition of MMR: & & & & \\
6 months & 0.90 & 4.87 & 94.17 & 0.06 \\
9 months & 4.25 & 7.39 & 87.43 & 0.93 \\
Variance Decomposition of EFP: & 14.74 & 6.26 & 76.94 & 2.06 \\
3 months & & & & \\
6 months & 0.81 & 0.18 & 44.12 & 54.89 \\
9 months & 0.81 & 5.19 & 43.38 & 50.62 \\
\end{tabular}

Figure 3. Response of UNR to MMR Shocks

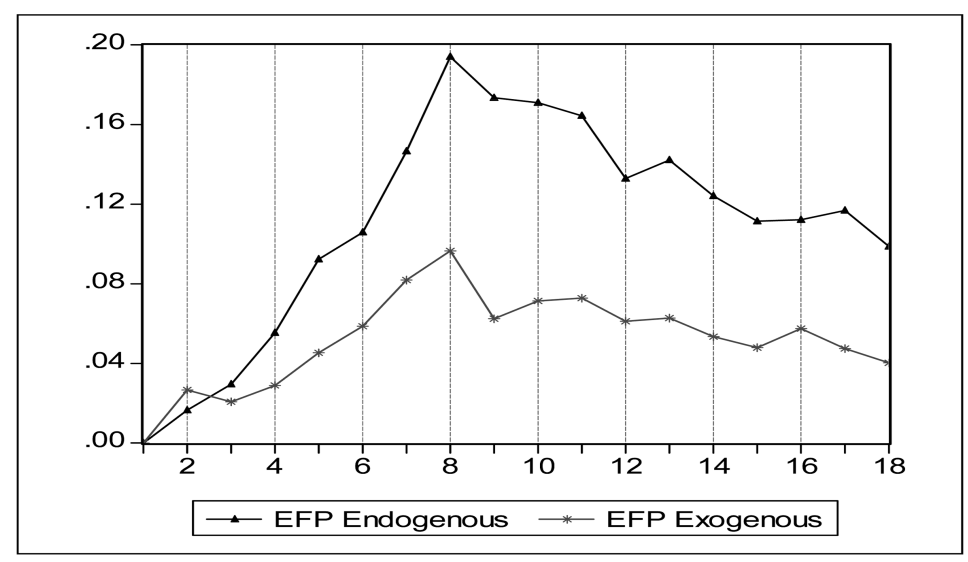

rates innovations are an important determinant of fluctuations in economic activity a result consistent with previous studies in US.

In a last step of our empirical investigation, we gauge the role of the corporate bond market in the transmission mechanism of the monetary policy to real activity by calculating and comparing two sets of impulse responses: one with the variable of the external finance premium treated as an endogenous in the VAR and another where it is included as an exogenous variable. The latter procedure generates a 
VAR identical to the former (with identical orthogonalized innovations) except that it effectively blocks off any responses within the VAR that passes through the EFP variable. Comparison of the unemployment responses of the two models thus provides a measure of the importance of that particular channel in acting as a conduit for monetary policy to the real economy (similar analysis applied by Bayoumi and Morsink (2001) for the Japanese economy). As shown in figure 3, after six months, the response of unemployment rate is much lower when the balance sheet channel, acting through the EFP, is blocked off. Even if there is no time lag between the two cases in unemployment responses, it can be indicated the significant effect of this channel.

\section{Conclusions and Policy Suggestions}

This paper indicates that the corporate bond spread can be used as a leading indicator of economic activity and it plays a crucial role on the transmission of monetary policy to real economy, results with important implications for policy makers and investors.

The significant role of financial markets on economic activity over the last years and the theory of financial accelerator in monetary policy transmission mechanism justify the important role that may play the corporate bond spread in the economy. This spread reflects the liquidity risk and the default risk, which convey information about the business cycle.

Our results of the GMM estimations indicate that it can contain information about the unemployment rate change 2 to 6 months horizon, as increases on EFP, precedes the increase in unemployment rate. However, the most significant effect on unemployment rate has been indicated over the short horizons. Even after the inclusion of the term structure variable the results about the significance of the corporate bond spread are not affected. This indicates that the corporate bond spread defined in this paper reflects information that is not captured by term structure of interest rates that reflects inflation expectations and monetary policy. The use of the two variables together can provide useful information about economic activity.

When external finance premium increase and term structure spread decrease significantly, they can signal an expected increase in the unemployment rate that will take place after two to six months. An indication of a worsening economic environment provides useful information for foreign and local investors. Term 
structure of interest rates contains information about short term rates and expected inflation, while external finance premium contains information about leverage conditions and financial wealth of corporations. Investors can build up their investment decisions based on such information provided.

Secondly, this paper also provides evidence for the important role of the corporate bond spread in the monetary transmission mechanism. By using impulse response functions based on a multivariate VAR model, we found that an initial monetary policy shock it has an effect on unemployment rate that reaches a peak after eight months. The effect of monetary policy shock to EFP variable is positive and quite persistent. The unemployment rate initially responds significant positively to an EFP shock and starts to decline after eight months. Another important finding is that, the response of unemployment rate is much lower when channel acting through the EFP is blocked off.

Policy makers can understand the important role of corporate bond market in the transmission mechanism of monetary policy. An easing monetary policy can be more effective when the yield spread between corporate bonds and government bonds is at low levels rather than at high levels. Similarly an increase in short term interest rates can have much greater effect from the initial one estimated on economic activity due to the operative balance sheet channel in Korea. Consequently, an efficient and liquid corporate bond market is of essential meaning for the Korean economy. A series of measures should immunize the efficient operation of this market

Finally, an interesting subject for future work, rising from this research, is to compare the role of corporate bond market on economic activity among other Asian countries. Moreover, the investigation of any non-linear relation between corporate bond market yields and economic activity measures can be another interesting subject. Finally, it is surely important to be investigated the main determinants of corporate bond yields in Emerging and Developed countries.

Received 25 October 2007, Revised 30 June 2008, Accepted 16 October 2008

\section{References}

Ashcraft, A.,B. and Campello, M. (2007), "Firm Balance Sheets and Monetary Policy Transmission", Journal of Monetary Economics, 54, pp. 1515-1528.

Barran, F., Coudert, V., Mojon, B. (1997), "Interest Rates, Banking Spreads and Credit 
Supply: the Real Effects", The European Journal of Finance, 3, pp. 107-136.

Bayoumi, T., Morsink. J. (2001), “A Peak inside the Black Box: the Monetary Transmission Mechanism in Japan”, IMF Staff Papers, 48 (1), pp. 22-57.

Bernanke BS, Gertler M, Gilchrist S. (1996), "The Financial Accelerator and the Flight to Quality", Review of Economics and Statistics, 78, pp. 1-15.

Bernanke, B., Blinder, A. (1992), "The Federal Fund Rate and the Channels of Monetary Transmission”, American Economic Review, 82 (4), pp. 901-921.

Bernanke, B., Gertler, M. (1995), "Inside the Black Box: the Credit Channel of Monetary Policy Transmission", Journal of Economic Perspectives, 9 (4), pp. 27-48.

Buttiglione, L., Ferri, G. (1994), "Monetary Policy Transmission via Lending Rates in Italy: Any Lessons from Recent Experience?", Banca d' Italia, Discussion Paper No. 224.

Cecchetti, S. (1999), "Legal Structure, Financial Structure, and the Monetary Policy Transmission Mechanism", Economic Policy Review, Federal Reserve Bank of New York 5, July, pp. 9-28.

Chan-Lau, J., Ivaschenko, I. (2001), "Corporate Bond Risk and Real Sctivity: an Empirical Analysis of Yield Spreads and their Systematic Components", IMF Working Paper, 01/158.

Chrystal A., Mizen, P. (2002), "Modelling Credit in the Transmission Mechanism of the United Kingdom", Journal of Banking and Finance, 26 (11), pp. 2131-2154.

Dale, S., Haldane, G. (1995), "Interest Rates and the Channels of Monetary Transmission: Some Sectoral Estimates", European Economic Review, 39 (9), pp. 1611-1626.

Davidson, R., McKinnon, J. (1993), Estimation and inference in Econometrics (Oxford University Press).

De Bondt, GJ. (2000), Financial Structure and Monetary Transmission in Europe: A Cross-Country Study. Edward Elgar: Cheltenham, UK/Northampton, MA, USA.

De Bondt, GJ. (2004), "The Balance Sheet Channel of Monetary Policy: First Empirical Evidence for the Euro Area Corporate Bond Market", International Journal of Finance and Economics, 9, pp. 219-228.

Ding, W., Domac, I., Ferri, G. (1998), "Is there a Credit Crunch in East Asia?", The World Bank, Working Paper 1959.

Domac, I., Ferri, G. (1998), "The Real Impact of Financial Shocks. Evidence from the Republic of Korea", The World Bank, Working Paper 2010.

Duca, J.V. (1999), "What Credit Market Indicators Tell Us", Economic and Financial Review, Federal Reserve Bank of Dallas, Third Quarter, pp. 2-13.

Elliott, G., Rothenberg, T., Stock, J. (1996), "Efficient Tests for an Autoregressive Unit Root", Econometrica, 64 (4), pp. 813-836.

Escriva, J., Haldane, G. (1994), "The Interest Rate Transmission Mechanism: Sectoral Estimates for Spain”, Banco de Espana, Discussion Paper No. 9414.

Estrella, A., Hardouvelis, G. (1991), "The Term Structure as a Predictor of Real Economic Activity", The Journal of Finance, 46 (2), pp. 555-576.

Estrella, A., Mishkin, F. (1998), "Predicting US Recessions: Financial Variables as Leading Indicators", Review of Economics and Statistics, 80, pp. 45-61. 
Favero, C. (2001), Applied Macroeconometrics, Oxford University Press, Oxford UK

Fountas, S., Papagapitos, A. (2001), “The Monetary Transmission Mechanism: Evidence and Implications for European Monetary Union", Economics Letters, 70 (3), March, pp. 397-404.

Friedman, B., Kuttner, K. (1992), "Money, Income, Prices and Interest Rates”, American Economic Review, 82 (3), pp. 472-492.

Friedman, B., Kuttner, K. (1998), "Indicator Properties of the Paper-Bill Spread: Lessons from Recent Experience", The Review of Economics and Statistics, 80 (1), pp. 34-44.

Gallant, R., Tauchen, G. (1996), "Which Moments to Match?", Econometric Theory, 12(4), pp. 657-681.

Gallegati, M. (2005), "Financial Constraints and the Balance Sheet Channel: a Reinterpretation", Applied Economics, 37, pp. 1925-1933.

Gertler M, Lown C. (1999), "The Information in the High-yield Bond Spread for the Business Cycle: Evidence and Some Implications", Oxford Review of Economic Policy, 15(3), pp. 132-150.

Hahm, J., Mishkin, F. (2000), "The Korean Financial Crisis: an Asymmetric Information Perspective", Emerging Markets Review, 1, pp. 21-52.

Hamilton, J. (1994), Times Series Analysis, Princeton University Press.

Hansen, L (1982), "Large Sample Properties of Generalized Method of Moments Estimators", Econometrica, 50, pp. 1029-1054.

Hosono, K. (2006), "The Transmission Mechanism of Monetary Policy in Japan: Evidence from Banks' Balance Sheets", Journal of the Japanese and International Economies, 20, pp. 380-405.

Kashyap, A., Stein, J., Wilcox, D. (1993), "Monetary Policy and Credit Conditions: Evidence from the Composion of External Finance", American Economic Review, 83 (1), pp. 78-98

Kim, H. (1999), "Was the Credit Channel a Key Monetary Transmission Mechanism following the Recent Financial Crisis in the Republic of Korea?", The World Bank, Working Paper 2103.

Mody, A., Taylor, M. P. (2003), "The High Yield Spread as Predictor of Economic Activity: Evidence of a Financial Accelerator Theory for the United States", IMF Staff Papers, 50 (3), pp. 373-402.

Mody, A., Taylor, M. P. (2004), "Financial Predictors of Real Activity and the Financial Accelerator", Economics Letters, 82, pp. 167-172.

Nagahata, T. and Sekine, T. (2005), "Firm Investment, Monetary Transmission and Balance-sheet Problems in Japan: an Investigation Using Micro Data", Japan and the World Economy, 17, pp. 345-369

NBER (2001), November Report on Business Cycle Dates. Available at http:// www.nber.org/cycles/november2001/ as of 26 November 2001

Newey, W.K., West, K.D. (1987), “A Simple Positive Semi-definite, Heteroscedasticity and Autocorrelation Consistent Covariance Matrix", Econometrica, 55, pp. 703-708

Papadamou, S. (2007), "Yield Spreads and Real Economic Activity in East European 
Transition Economies", Applied Economics Letters, 16, pp. 531-537.

Paya, I. and Matthews, K. (2004), "Term Spread and Real Economic Activity in Korea:

Was the Crisis Predictable?", Applied Economics Letters, 11, pp. 797-801.

Perron, P., Ng, S. (1996), "Useful Modifications to Some Unit Root Tests with Dependent

Errors and Their Local Asymptotic Properties", Review of Economic Studies, 63 (3),

July, pp. 435-465.

Sims, C., Stock, J., Watson, M. (1990), "Inference in Linear Time Series Models with

Some Unit Roots", Econometrica, 58 (1), pp. 113-144.

Verbeek, M. (2004), A Guide to Modern Econometrics, John Wiley \& Sons Ltd. 